\title{
Оценка современного состояния материально-технической базы морских портов Краснодарского края в сфере пассажирских перевозок
}

\author{
А. А. Филобок, А. П. Турлучев $ه$ \\ Кубанский государственный университет, Российская Федерация \\ (350040, г. Краснодар, ул. Ставропольская, 149)
}

\begin{abstract}
Аннотация: Цель. Провести анализ пространственного распределения операторов морских пассажирских терминалов Краснодарского края и показателей их материально-технической базы.

Maтериалы и методы. Исходным материалом для проведения настоящего исследования являются сведения из реестра морских портов Российской Федерации 2018 года, содержащие сведения о материально-технической базе операторов морских терминалов в пределах отдельно взятого морского порта. Применены методы моделирования, системного, статистического и сравнительного анализа, компьютерной обработки и визуализации пространственных данных.

Результаты и обсуждение. В границах исследуемой территории, пассажирские перевозки осуществляются 12 операторами, использующими 24 морских пассажирских терминала. Наибольшие значения технической группы показателей, с точки зрения пространственного распределения, сконцентрированы в районах морских портов Сочи и Новороссийск. Распределение производственных показателей, в первую очередь обусловлено спецификой деятельности операторов пассажирских терминалов. Структура организационно-правовых форм операторов морских пассажирских терминалов, включает в себя 2 акционерных общества, 7 обществ с ограниченной ответственностью, 2 филиала Федерального государственного унитарного предприятия «Росморпорт» и 1 индивидуального предпринимателя.

Заключение. В настоящее время, материально-техническая база морских портов в сфере пассажирских перевозок представлена 24 терминалами, расположенными в 5 портах Краснодарского края. Операторами пассажирских терминалов являются преимущественно частные компании, организованные в форме обществ с ограниченной ответственностью и акционерных обществ. Пространственное распределение пропускной способности пассажирских терминалов определяется направлением деятельности операторов.
\end{abstract}

Ключевые слова: Морские порты, Азово-Черноморский бассейн, Краснодарский край, морские пассажирские перевозки.

Для цитирования: Филобок А.А., Турлучев А.П. Оценка современного состояния материальнотехнической базы морских портов Краснодарского края в сфере пассажирских перевозок // Вестник Воронежского государственного университета. Серия География. Геоэкология, 2020, №3, с. 56-60. DOI: https://doi.org/10.17308/geo.2020.3/3024

\section{ВВЕДЕНИЕ}

Особенности физико- и экономико-географического положения определили вектор развития Краснодарского края, побережье которого остается одним из главных курортных регионов России. В 2018 году Краснодарский край обеспечил размещение более 17 млн. туристов, большинство из которых нацелены на пляжный и морской туризм [1]. Мировая индустрия туризма обладает наибо- лее интенсивной динамикой развития в международной торговле услугами. В последние 20 лет среднегодовой прирост количества зарубежных путешественников в мире достиг $5,1 \%$, а валютных поступлений $-14 \%$. Характерная особенность туристской деятельности в Краснодарском крае - сезонность туристского потока. В силу отсутствия необходимой пропускной способности железнодорожных и автомобильных дорог, в разгар турист-

() Филобок А. А., Турлучев А.П., 2020

\ Турлучев Антон Павлович, e-mail: turluchev.a.p@gmail.com

Контент доступен под лицензией Creative Commons Attribution 4.0 License. 

пассажирских перевозок

ского сезона, с июня по сентябрь наблюдается перегруженность наземных путей сообщения. Все виды транспортных систем преследуют единственную цель - наиболее полное удовлетворение потребностей путешественников при реализации услуг по перевозке [2]. Транспортные заторы, на фоне увеличивающихся запросов Российских и иностранных туристов негативно сказываются на удовлетворенности условиями отдыха. На пике туристского сезона, необходимость наличия альтернативных путей сообщения, обеспечивающих увеличение мобильности отдыхающих, проявляется наиболее остро. Перспективное направление развития - организация морских пассажирских перевозок, что определяет цель настоящего исследования, а именно: проведение оценки текущего состояния материально-технической базы морских портов Краснодарского края в сфере морских пассажирских перевозок.

\section{МАТЕРИАЛЫ И МЕТОДЫ ИССЛЕДОВАНИЯ}

В качестве исходных данных были использованы сведения из реестра морских портов Российской Федерации 2018 года, содержащие сведения о материально-технической базе операторов морских терминалов в пределах каждого морского порта.

В настоящем исследовании применялись методы моделирования, системного, статистического и сравнительного анализа, компьютерной обработки и визуализации пространственных данных.

Поскольку исходные данные были представлены отдельными файлами по каждому морскому порту, они были сведены в единую электронную таблицу, состоящую из 21 поля характеристик морских терминалов и 79 записей по каждому отдельному морскому терминалу Азово-Черноморского бассейна Краснодарского края. В целях реализации настоящего исследования, была проведена агрегация данных по нескольким критериям.

1. По критерию наличия значений в графе пропускной способности пассажирских морских терминалов, в результате чего была создана сводная таблица, включающая 24 записи и содержащая характеристики каждого морского терминала, пригодного для организации пассажирских перевозок.

2. По критерию наличия значений в графах пропускной способности пассажирских морских терминалов и оператора морского терминала - создана сводная таблица, содержащая сведения о совокупных характеристиках каждого отдельного оператора морских терминалов (12 записей).
3. По критерию наличия значений в графах пропускной способности пассажирских морских терминалов и принадлежности к морскому порту - создана сводная таблица, содержащая сведения о количестве операторов морских пассажирских перевозок и совокупных характеристиках пассажирских терминалов в каждом порту (6 записей).

\section{РЕЗУЛЬТАТЫ И ОБСУЖДЕНИЕ}

На территории Краснодарского края пассажирские перевозки осуществляются 12 операторами, использующими 24 морских пассажирских терминала, которые расположены в портах Черного (Анапа, Геленджик, Новороссийск, Сочи) и Азовского (Кавказ) морей. Крупнейшим, с точки зрения технической группы показателей, является морской порт Сочи, включающий 26 пассажирских причалов совокупной длинной более 3,2 км, площадью территории и акватории составляющими 13,5 га, и 17,4 кв. км соответственно. Второй порт - Новороссийск с 7 пассажирскими причалами совокупной длинной причального фронта более 1 км. Площадью территории пассажирских терминалов 4,7 га, а акватории 0,05 кв. км. Третьим по величине портом считается Кавказ. Количество причалов - 2, длинна причального фронта 528 м, площадь территории и акватории терминалов 2,9 га и 0,04 кв. км соответственно.

Анализ технических показателей операторов морских терминалов указывает на то, что они, как правило, ведут деятельность в пределах одного порта, за исключением ООО «Коммандор» присутствующего в морских портах Новороссийск и Геленджик и специализирующегося на организации морской экскурсионной и туристской деятельности.

Лидером технической группы показателей, среди операторов морских пассажирских терминалов является ОАО «Сочинский морской торговый порт», эксплуатирующий 19 причалов совокупной длинной более 2650 м и способный принимать суда длинной до 311 м и осадкой до 8,8 м. Технические характеристики порта позволяют принимать суда, такие как 14-ти палубный круизный лайнер Costa Diadema. За ним следует ПАО «Новороссийский морской торговый порт» с 3 пассажирскими причалами, совокупной длинной причального фронта 569 м, способный принимать суда с осадкой до 8,6 м и длинной до 185,4 м, такие как 7-и палубный круизный лайнер Deutschland. Далее следует Азово-Черноморский бассейновый филиал Федерального государственного унитарного предприятия «Росморпорт» (Новороссийск), способ- 
ный принимать суда длинной до 156,2 м и осадкой до 5,9 м.

Наибольшие значения технической группы показателей, с точки зрения пространственного распределения, сконцентрированы в районах морских портов Сочи и Новороссийск. Указанное обстоятельство объясняется спецификой географического положения, и в первую очередь рельефом дна, который для морских портов Кавказ, Геленджик и Анапа является фактором, ограничивающим возможность принятия судов с большей осадкой.

Анализ производственной группы показателей смещает акценты, влияющие на целостную характеристику материально-технической базы пассажирских терминалов морских портов Краснодарского края. При оценке пропускной способности становится очевидным, что совокупный показатель всех пассажирских терминалов Черноморского побережья не превышает показатель морского порта Кавказ. Может сложиться впечатление, что показатель пропускной способности пассажирских морских терминалов практически не зависит от технической группы показателей морских портов. Однако, наблюдаемый дисбаланс объясняется анализом информационной группы показателей. Прежде всего, стоит обратить внимание на показатель «основных технических характеристик морского терминала», указывающий на то, что в морском порту «Кавказ» показатель «пропускной способности пассажирского морского терминала» формируется за счет эксплуатации железнодорожного паромного (ООО «Анроскрым») и автодорожного паромного (ООО «Морская дирекция») терминалов, в то время как остальные терминалы являются либо пассажирскими, либо грузопассажирскими.

Таким образом, смещение производственных показателей, в первую очередь обусловливается спецификой деятельности операторов пассажирских терминалов. Для обеспечения полноты исследования, стоит провести оценку совокупных технических и производственных групп показателей относительно организационно-правовой формы операторов морских терминалов. Структура организационно - правовых форм операторов морских пассажирских терминалов включает в себя 2 акционерных общества с совокупной длиной причального фронта 3235,29 метров и пропускной способностью 862000 пассажиров в год, 7 обществ с ограниченной ответственностью, совокупная длина причального фронта которых, составляет 1067,73 метра, и способных обслужить в течение года 5915000 пассажиров, 2 филиала Федерального государственного унитарного предприятия «Росморпорт» с длинной причального фронта 800 метров и пропускной способностью пассажирских терминалов 1673800 человек в год и 1 индивидуального предпринимателя, эксплуатирующего 1 причал длинной 45 метров и пропускной способностью 30000 человек в год.

Оценка пространственного распределения операторов морских терминалов по организационноправовым формам демонстрирует, что в морских портах Анапа, Геленджик и Кавказ деятельность осуществляют по два юридических лица в форме обществ с ограниченной ответственностью. В морском порту Сочи операторами морских терминалов являются Акционерное общество и Федеральное государственное унитарное предприятие. Операторы терминалов морского порта Новороссийск представлены в форме Акционерного общества, Федерального государственного унитарного предприятия, двух обществ с ограниченной ответственностью и индивидуальным предпринимателем.

\section{ЗАКЛЮЧЕНИЕ}

Исследование структуры с одновременной оценкой пространственного распределения технических и производственных групп показателей операторов морских пассажирских терминалов, позволило дать наиболее целостную характеристику текущего состояния материально-технической базы морских портов Краснодарского края в сфере морских пассажирских перевозок.

В настоящее время, материально-техническая база морских портов в сфере пассажирских перевозок представлена 24 терминалами, расположенными в 5 портах Краснодарского края. Операторами пассажирских терминалов являются, преимущественно частные компании, организованные в форме обществ с ограниченной ответственностью и акционерных обществ. Пространственное распределение пропускной способности пассажирских терминалов определяется направлением деятельности операторов. Формально, максимальная пропускная способность пассажиров зафиксирована в морском порте Азовского моря (порт Кавказ) и обусловлена деятельностью железнодорожного и автодорожного паромных терминалов. Основным направлением деятельности операторов пассажирских терминалов морских портов Черного моря является предоставление туристских и экскурсионных услуг. В последние годы предпринимаются попытки реанимирования морских 
пассажирских перевозок в Азово-Черноморском бассейне, о чем свидетельствует запуск двухпалубных теплоходов «Аквалоо» по направлению Сочи - Туапсе и «Черноморье» - по направлению Тамань - Керчь. Осуществление круизного сообщения на теплоходе «Князь Владимир» и другие - не решают проблемы транспортной обеспеченности, поскольку являются не регулярными, преимущественно прогулочными и экскурсионными маршрутами.

\section{СПИСОК ЛИТЕРАТУРЫ}

1. Тимошенко Д. С., Епринцев С. А. Социально-экономические и экологические факторы, определяющие развитие и продвижение туристского потенциала Краснодарского края // Вестник Воронежского государственного университета. Серия: География. Геоэкология, 2019, № 4, с. 43-48.

2. Осипова О.Я. Транспортное обслуживание туристов. Москва, Академия, 2006. 376 с.

Конфликт интересов: Авторы декларируют отсутствие явных и потенциальных конфликтов интересов, связанных с публикацией настоящей статьи.

Поступила в редакиию 20.08.2019

Принята к публикации 26.07.2020

UDC 911.7

\title{
Assessment of the Current State of the Material and Technical Base of Seaports of the Krasnodar Region in the Field of Passenger Transportation
}

\author{
A. A. Filobok, A.P. Turluchev $\bowtie$ \\ Kuban State University, Russian Federation \\ (149, Stavropolskaya st., Krasnodar, 350040)
}

\begin{abstract}
The purposeis to analyze the spatial distribution of operators of sea passenger terminals of the Krasnodar region and the indicators of their logistics base.

Materials and methods: The source material for this study is information from the Russian Federation's 2018 Maritime Ports Registry, which contains information about the logistics base of sea terminal operators within a separate seaport. The methods of modeling, system, statistical and comparative analysis, computer processing and visualization of spatial data are applied.

Results and discussion: Within the boundaries of the study area, passenger transport is carried out by 12 operators using 24 offshore passenger terminals. The highest values of the technical group of indicators, in terms of spatial distribution are concentrated in the areas of seaports of Sochi and Novorossiysk. The distribution of production indicators is primarily due to the specifics of the activities of passenger terminal operators. The structure of organizationally - legal forms of operators of sea passenger terminals, includes 2 companies, 7 limited liability companies, 2 branches of the Federal State Unitary Enterprise Rosmorport and 1 individual entrepreneur.

Conclusion: Currently, the logistics base of seaports in the field of passenger transport is represented by 24 terminals located in 5 ports of the Krasnodar region. The operators of passenger terminals are mainly private companies organized in the form of limited liability companies and public companies. The spatial distribution of passenger terminal capacity is determined by the direction of operators.
\end{abstract}

Key words: Seaports, Azov-Black Sea basin, Krasnodar Region, sea passenger transportation.

For citation: Filobok A.A., Turluchev A.P. Assessment of the current state of the material and technical base of seaports of the Krasnodar region in the field of passenger transportation. Vestnik Voronezskogo gosudarstvennogo universiteta. Geografia geoekologia, 2020, No. 3, pp. 56-60. (In Russ.) DOI: https://doi.org/10.17308/geo.2020.3/3024

(C) Filobok A. A., Turluchev A.P., 2020

$\triangle$ Anton P. Turluchev, e-mail: turluchev.a.p@gmail.com

(i) The content is available under Creative Commons Attribution 4.0 License. 


\section{REFERENCES}

1. Timoshenko D.S., Eprintsev S. A. Sotsial'no-ekonomicheskie i ekologicheskie faktory, opredelyayushchie razvitie i prodvizhenie turistskogo potentsiala Krasnodarskogo kraya [Socio-economic and environmental factors determining the development and promotion of the tourism potential of the Krasnodar Region]. Vestnik Voronezskogo

кандидат географических наук, доцент кафедры экономической, социальной и политической географии Института географии, геологии, туризма и сервиса, Кубанский государственный университет, г. Краснодар, Российская Федерация, ORCID: https://orcid.org/0000-0002-7745-9472

Турлучев Антон Павлович

аспирант кафедры экономической, социальной и политической географии, Институт географии, геологии, туризма и сервиса, Кубанский государственный университет, г. Краснодар, Российская Федерация, ORCID: https://orcid.org/0000-0002-6515-2692, e-mail: Turluchev.a.p@gmail.com gosudarstvennogo universiteta. Geografia geoekologia, 2019, no. 4, pp. 43-48. (In Russ.)

2. Osipova O. Ya. Transportnoe obsluzhivanie turistov [Transport service for tourists]. Moscow, Academy, 2006. 376 p. (In Russ.)

Conflict of interests: The authors declare no information of obvious and potential conflicts of interest related to the publication of this article.

Received: 20.08 .2019

Accepted: 26.07 .2020

Anatoly A. Filobok

Cand. (Geogr.) Sci., Associate Professor of the Department of Economic, Social and Political Geography of the Institute of Geography, Geology, Tourism and Service, Kuban State University, Krasnodar, Russian Federation, ORCID: https://orcid.org/0000-0002-7745-9472

Anton P. Turluchev

Post-graduate Student of the Department of Economic, Social and Political Geography of the Institute of Geography, Geology, Tourism and Service, Kuban State University, Krasnodar, Russian Federation, ORCID: https://orcid.org/0000-0002-6515-2692, e-mail:

Turluchev.a.p@gmail.com 